\title{
The Religious Schema Scale: Construction and Initial Validation of a Quantitative Measure for Religious Styles
}

\author{
Heinz Streib \\ Center for Biographical Research in Contemporary Religion \\ Universität Bielefeld \\ Ralph W. Hood Jr. \\ Department of Psychology \\ University of Tennessee at Chattanooga \\ Constantin Klein \\ Center for Biographical Research in Contemporary Religion \\ Universität Bielefeld
}

\begin{abstract}
This article presents the Religious Schema Scale (RSS). Its conceptual background is the model of religious styles. After a conceptual discussion of the relation between religious styles and religious schemata, the steps of scale construction are reported. Based on 822 responses from research participants in the United States and Germany to a preliminary 78-item version, we used construct-oriented iterative and factor-analytic procedures for reducing the RSS to a 15-item version that consists of three 5-item subscales with acceptable reliabilities. Confirmatory factor analysis indicates that the RSS has a robust 3-factor structure, which is cross-culturally valid in both the United States and Germany. We report correlations of the RSS with the Big Five, Psychological Well-Being, Religious Fundamentalism, and Right-Wing Authoritarianism. We also present predictive characteristics of the RSS in regard to Fowler's stages of faith. Finally, we report results on the incremental validity of the RSS.
\end{abstract}

Correspondence should be sent to Heinz Streib, Center for Biographical Research in Contemporary Religion, Universität Bielefeld, Postfach 100131, 33501 Bielefeld, Germany. E-mail: Heinz.Streib@ uni-bielefeld.de 
This article presents a new measure for difference in religious styles and schemata: the Religious Schema Scale (RSS). This measure brings something new to the tradition of research in religious development, because it is based on a new model that addresses criticisms applied to the sequentiality and "structural wholeness" of stages of faith asserted by Fowler's (1981) model of faith development. Certainly, modeling and investigating structural differences of religiosity has received strong impulses from Fowler's (1981) work: There are more than 50 independent faith development research projects published (Streib, 2003, 2005), most of which have used the classical Faith Development Interview, but part of them also used quantitative measures. The issue is more complex when one recognizes the serious conceptual criticism against Fowler's stage theory ignored by current quantitative proposals to measure Fowler's now classic stages. Thus, because the RSS is based on a revised model that addresses the major conceptual criticisms of Fowler's classic model, we need to start with a discussion of the conceptual framework, before we go into the details of scale construction and initial validation of our proposed quantitative measure.

\section{CONCEPTUAL FRAMEWORK}

\section{Fowler's Model of Faith Development and the Religious Styles Perspective}

Fowler (1981) introduced a model of stages of meaning-making that by definition feature six structurally distinct patterns of faith and that he labeled intuitive-projective, mythic-literal, synthetic-conventional, individuative-reflective, conjunctive, and universal faith. Fowler's concept of "faith" is well grounded in a specific theory of religion (Smith, 1963, 1979) and far-sighted with respect to the spiritual questing of today that can, but need not, occur outside specific religious traditions (Hood, 2003; Zinnbauer \& Pargament, 2005). Insofar as faith is conceived by Fowler as a human universal, it can be distinct from particular religious traditions and belief systems (cf. Hood, 2003) and is characterized by meaning-making (cf. Park, 2005) and by interpretation of experiences and loyalty to values in relation to people's constructions of an ultimate environment.

It is consistent with such universal and broad definitional starting point, that Fowler found it adequate to include a variety of seven domains all of which he regarded as aspects of faith: logic (Piaget), perspective-taking (Selman), moral judgment (Kohlberg), social awareness, authority, world coherence, hermeneutics of symbols. In regard to empirical assessment, Fowler talks about "windows" to a person's faith and assumes a multidimensional coherence between all of these seven aspects-which, viewed from the contemporary state of the discussion in developmental psychology, appears as problematic reduction of complexity in theory and research. Fowler conceptualized "stage" and "development" primarily along the lines of Kohlberg, Levine, and Hewer's (1983) criteria for (hard) stage models (even though not everyone in the field was convinced that Fowler's theory in fact can be called a hard stage theory, e.g., Power, 1991). Hard stage models require that a "stage" have coherence, a stage is a priori presupposed as "structural whole" across domains and aspects. Development in hard stage models is assumed to be one-directional, sequential, and 
irreversible. However, these assumptions no longer are acceptable in light of research which indicates that children and adults may not be altogether different in their thinking (see, e.g., Boyatzis, 2005). Neither these problems nor other ones related to problems within Piaget's work and neo-Piagetian models (see, e.g., Day, 2007, 2008; Streib, 2001), have been taken into account by Fowler, even in his most recent work (Fowler \& Dell, 2006). Fowler did not change or revise his model but argued for consistency with theological, ego-psychological, and psychoanalytic constructs and addressed primarily a theological audience. The project of reconstructing and operationalizing the faith development perspective in the terms of psychology has only begun.

The introduction of the concept of style can be viewed as first step of a revision of faith development theory (Streib, 2001) and research (Streib, 2005). The religious styles perspective adopts the characterization of structural patterns of religiosity from Fowler but suggests retreating from the a priori premises for the cognitive-structural "logic of development," especially from the assumption of "structural wholeness," and instead relying on empirical evidence with respect to religious development. As a consequence, décalage (the time lag of development in one domain compared to another domain) is regarded as the rule rather than the exception (Canfield \& Ceci, 1992). Whereas a faith stage is defined by operational structures that are assumed to be coherent across domains, a religious style is-more pragmatically and empirically open-constituted by the repetitive use of a certain pattern.

The religious styles perspective moreover implies that religious structures are not abandoned when new developments emerge but recede into the background where they may remain dormant and available for further use. Thus, the religious styles perspective acknowledges the possibility of the simultaneous presence of different structural patterns —or distinguishing marks for styles - in the religiosity of one and the same person at a given time. This is more consistent with empirical data which in part present a Fowler faith stage range of two stages or more, especially in fundamentalist orientations (Streib, 2001, 2007).

If we, however, retreat from the assumption of consistent operational structures across domains (structural wholeness that defines a stage) and reckon with the possibility of a simultaneous presence of more than one style in the same person at a given time, it can no longer be the sole aim in research to identify a single stage score by simply calculating an average, but evaluation has to account for difference and thus needs more precise distinguishing marks for a specific religious style. This is especially necessary in quantitative research-and the work reported in this article is devoted to the question how religious styles can be assessed in quantitative research. This requires the definition of distinguishing marks that are indicative of specific religious styles and also indicative of Fowler's stages of faith.

\section{Distinguishing Marks for Religious Styles: Schemata}

Our concept of "schema" relates to McIntosh's (1995) religion-as-schema proposal which has influenced research on religious coping and meaning (Park, 2007); but our schema concept features a precise definition resting on the key characteristic that schemata link an experience with an interpretation. We thus define a schema as cognitive pattern of how a person (a) seeks out and prefers a specific interpretation for coping with and transforming a specific challenging 


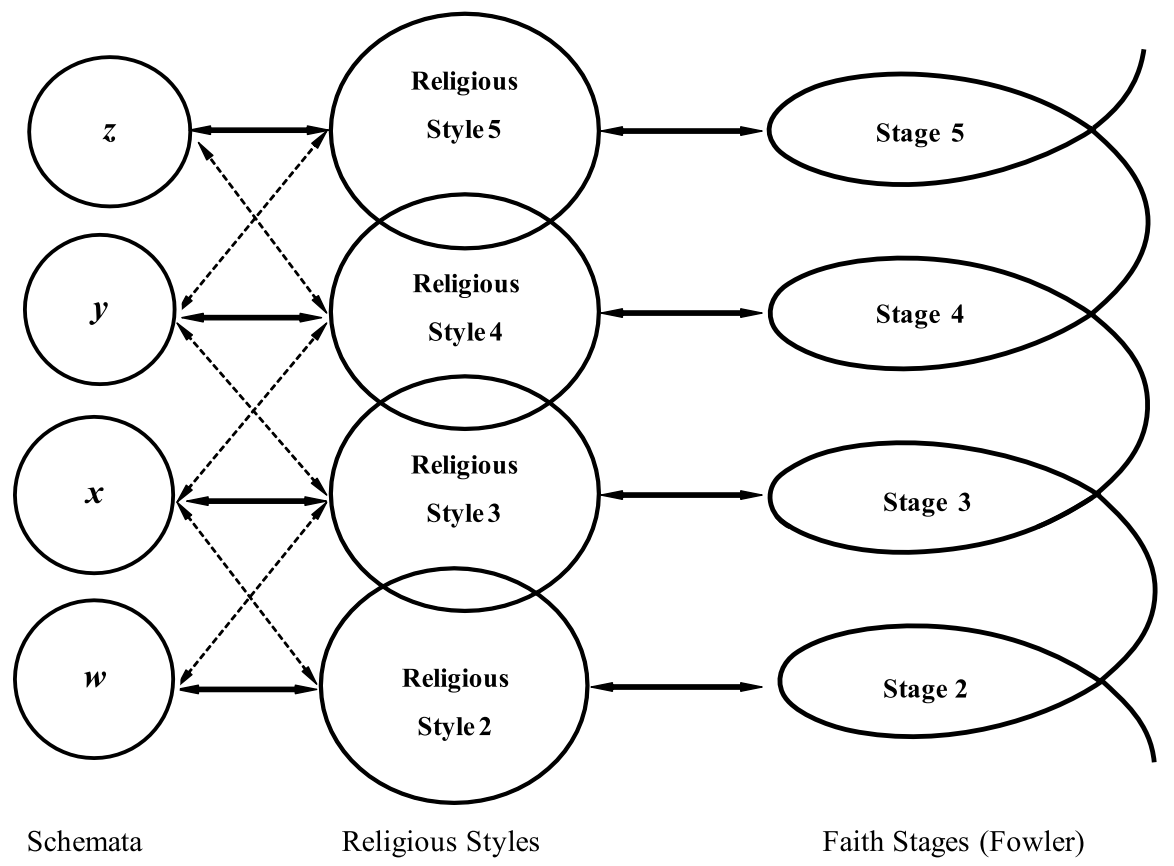

FIGURE 1 Relation of religious schemata, religious styles and faith stages.

experience and (b) how this person constructs a specific interpretation for the cause of the challenging experience against which he or she is ready to act. ${ }^{1}$

Whereas schemata are conceptualized as precise structural patterns of interpretation and praxis, styles, according to our pragmatic definition, emerge from the repetitive use of specific schemata. Religious styles resemble—and relate to-lifestyles and to habitus (Bourdieu, 1979). ${ }^{2}$ Religious schemata are the distinguishing marks for religious styles. Our proposal of how to envision the association of religious schemata, religious styles and Fowler's stages of faith can be seen in Figure 1. The conclusion for empirical research in terms of religious styles is this: We need to be explicit about what the RSS is supposed to measure with some precision (schemata) and what the RSS subscales as distinguishing marks might indicate (styles). The RSS is designed as an operational measurement of schemata in order to assess religious styles.

\footnotetext{
${ }^{1}$ A schema consists of two components, two corresponding acts of interpretation: Challenging experiences such as personal, social, or ecological threat and catastrophe call for an interpretation of hope and for coming to terms with the catastrophe. This is accomplished by the first component of a schema that gives meaning to these experiences (epistemological transformation) and opens the perspective on a positive experience. The other component of the schema starts with the positive experience and seeks out an interpretation that identifies potential dangers, the sources for the challenging experience, and thus motivates action (praxeological transformation). This understanding of "schema" corresponds to Schäfer's (2003, in press) model of "praxeological squares," which he has developed with reference to Greimas's (1987) semiotic square.

${ }^{2}$ Thus, models of identity as network such as Schäfer's (2005) parallel our model of religious schemata, which network together in the formation of religious styles.
} 
The figure also indicates that religious schemata relate not only to religious styles (sensu Streib) but also to faith stages (sensu Fowler), if faith stages are interpreted in terms of the religious styles perspective, which implies the retreat from assumptions of "structural wholeness" and from a predefined "logic of development." Fowler's faith stages and Streib's religious styles correspond in their characterization of the various structural patterns of religiosity. Thus the religious schemata of the RSS relate to Fowler's stages of faith but allow for an independent assessment of difference, décalage and overlap of faith structures.

The RSS has a clear focus on a specific dimension of religious styles: on the spectrum between a more fundamentalist orientation on the one hand and tolerance, fairness, and openness for dialog on the other-which is most pertinent in face of interreligious relations in our globalized world. Thus, our model resonates with a variety of recent contributions such as the polarization of tolerance and fundamentalism (Altemeyer \& Hunsberger, 1992, 2005) or the polarization of religious exclusivism and pluralism (Gennerich \& Huber, 2006; Huber, 2009; Huber \& Klein, 2007). However, our model introduces and highlights something new: the dialogical attitude we call xenosophia. This appreciation of the wisdom in encounter with the alien of course relates to Fowler's ingenious idea of assuming stages of faith beyond the individuative-reflective style, thus conceptualizing a style that he called "conjunctive faith" and that features the appreciation of the other and other faith traditions. This can be further grounded and sharpened with reference to Waldenfels's $(1990,1997)$ and Nakamura's $(2000)$ philosophical contribution to a theory of the alien from which the concept of xenosophia has emerged. Xenosophia means something more than pluralism, namely, appreciation for the creative surplus of the encounter with the alien.

Three schemata, ttt (truth of text and teachings), ftr (fairness, tolerance and rational choice), and xenos (xenosophia, inter-religious dialog), as explained in more detail next, are included in the RSS. They are not independent structural units but part of a dynamic field with multiple interactions. This dynamic model can be envisioned as triangle in which the three schemata are connected with arrows in both directions (see Figure 2).

To explain this briefly and give examples: The schema $t t t$ can be mediated through $f t r$; such is the case, when a person of primarily style-two fundamentalist orientation moves, through

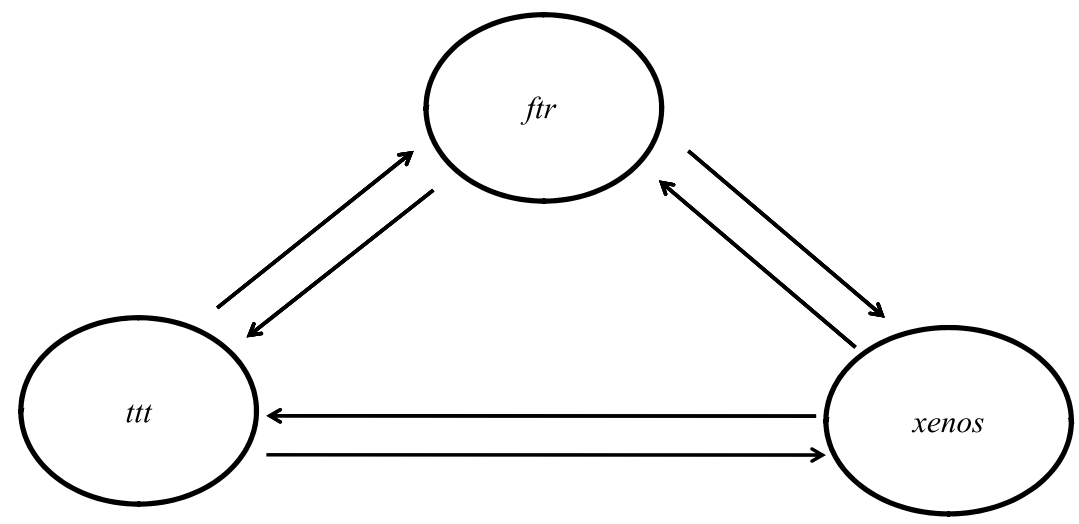

FIGURE 2 The Dynamic Model of Religious Schemata 
increasing openness for a new style pattern, toward rating ftr higher and preferring a fair, tolerant, and rational style. But also the opposite is possible-which is the case with persons who use a rational style to defend their fundamentalist style. Also, ftr can be mediated through xenos as when a person with a primarily tolerant and rational style moves on to the appreciation of an open-ended dialog and creative encounter with the alien. But also here we can imagine a retreat to the rational defense of pluralism or a specific world view. Finally, ttt can be mediated through xenos - which could be the case for persons with rather strong emphasis on their own religious tradition, but come to hold it in an "as-if" or "equal-to-others" mode, thus with openness for dialog and encounter. Or the other way around: A person with a primary interreligious style preference could retreat to defend his or her view with the absoluteness of a "religion." These are just examples to illustrate the dynamic interaction between the schemata and are not meant to suggest that every person oscillates between the schemata, but the account for such dynamic is important to note, because it profiles the difference between our model of schemata and the cognitive-structural model of sequential and irreversible stages.

\section{RATIONAL UNDERLYING THE CONSTRUCTION OF THE RELIGIOUS SCHEMA SCALE}

The construction of the Religious Schema Scale is a contribution to the scale developments that quantitatively assess religious style diversity. The desire for a quantitative measure for research in faith and religious development has been repeatedly noted (e.g., by Burris, 1999), and some measures have been proposed (e.g., Leak, 2003, 2008; Leak, Loucks, \& Bowling, 1999). However, the previous scales sought no more than measuring Fowler's stages, are rather too short, have a Christian bias, and do not question Fowler's model as is critically discussed elsewhere (Streib, 2003, 2005). The RSS is different as it is based on the previously explained revision and modification of Fowler's model that address the major criticism of stage theories. Our revision preserves, promotes, and clarifies the idea of style differences, including a strong emphasis on the innovative construct of xenosophia. Accordingly we report the operationalization of our model: the procedure of construction, reduction, and validation of the Religious Schema Scale.

\section{METHOD}

\section{Participants}

The Bielefeld-Based Cross-Cultural Study of Deconversion (Streib, Hood, Keller, Csöff, \& Silver, 2009) compared more than 100 deconverts to more than 1,000 persons who stayed within their tradition $(N=1,196)$. Research participants were (or had been) members in a variety of religious groups including mainstream Christian churches but also non-Christian minority oppositional groups. Besides qualitative instruments such as the narrative interview and the Faith Development Interview (FDI), an extensive questionnaire has been administered. In this questionnaire we included, in the second phase of field work, the initial 78 
items to assess religious styles; these have been answered by 822 respondents, $31 \%$ from Germany and 69\% from the United States: 6.8\% were deconverts from and $93.2 \%$ were members in religious organizations. With $41 \%$ male and $59 \%$ female respondents, gender distribution is acceptable. All age groups are present in the sample $(M=29.34, S D=$ 15.29 , range $=13-84$ ), but, with $60.2 \%$ younger than 25 years old, age distribution is not equal.

\section{Measures}

Besides the initial 78 items for religious style assessment, ${ }^{3}$ the questionnaire has included a number of measures which were designed for the assessment of preconditions and outcomes of deconversion: the Big Five personality measure in its revised NEO-FFI version (Costa \& McCrae, 1985)—especially the subscale openness to experience is important in this textthe Psychological Well-Being Scale (Ryff \& Singer, 1996)—here, especially the subscales personal growth and purpose in life were regarded important-the Religious Fundamentalism Scale (Altemeyer \& Hunsberger, 1992) and the Right-Wing-Authoritarianism Scale (Altemeyer, 1996). All measures are detailed in the research report (Streib et al., 2009). The measures either had an official German translation or were translated into German and back-translated for control. Most scales have been presented in a 5-point Likert-type format from strongly agree to strongly disagree. From a subsample of 104 respondents (60 from Germany, 44 from the United States), we have, besides the responses to the questionnaire, the FDI, which has been administered and evaluated according to the Manual for Faith Development Research (Fowler, Streib, \& Keller, 2004). This unique data structure allows for the validation of the RSS in relation to the classical faith development instrument.

\section{Procedure}

For item reduction of the initial 78-item measure, construct-oriented iterative reduction and Principal Component Analysis have been combined. Construct-oriented iterative reduction has been used, for example, by Ryff and Singer (2006) in reducing the number of items in the Psychological Well-Being Scale. In the process of iterative item reduction, items are removed one by one. Criteria thereby were not only (least) factor loadings but also reliabilities, conceptual judgment on construct validity, and equal size of subscales. The result of this construct-oriented iterative reduction, the - theoretically plausible-15-item, three-factor solution, has been tested for its fit with our data by confirmatory factor analysis (CFA) using our entire and country-wise split sample. Further, correlation analysis was used to assess the internal relation of the RSS subscales and their relation with other measures. Finally, for a test of incremental validity of the RSS, multiple regression analysis has been performed.

\footnotetext{
${ }^{3}$ Our initial construction of the 78 items has some commonality with Clore's (1997) construction of a Faith Scale and consists of sets of style-specific items; the sets are designed to assess certain aspects of faith. Although Clore was rather selective, compared with Fowler's aspect structure, we have expanded the number of aspects and items and added three new item sets for the image of God and three new item sets for interpersonal relations. The result was the initial 78-item measure that has been included in the questionnaire.
} 


\section{RESULTS}

\section{Identification of Factor Structure and Subscales}

In the construct-oriented iterative reduction, exploratory factor analysis indicated that a threefactor solution is the best solution for both the combined and the split U.S. and German sample. Thus, corresponding to the three factors, three subscales have been constructed according to high factor loadings, consistency with marker items, reliability, and construct validity. These subscales are Truth of Texts and Teachings (ttt); Fairness, Tolerance \& Rational Choice ( ftr); and Xenosophia/Interreligious Dialog (xenos). The $t t t$ subscale (sample item: "What the texts and stories of my religion tell me, is absolutely true and must not be changed.") corresponds to, and is supposed to be indicative of, the mythic-literal faith of Fowler's stage two and to the instrumental-reciprocal religious style (Streib, 2001). The ftr subscale (sample item: "We should resolve differences in how people appear to each other through fair and just discussion.") relates to the individuative-reflective faith of Fowler's stage four and to the religious style that Streib (2001) labeled individuative-systemic. At first sight, ftr may appear unrelated to religion, but it is, in our view, as strongly related to religion as Fowler's individuative-reflective faith, namely, assessing a tolerant, fair, rational, and reflexive dealing with religious pluralism. Finally, the xenos subscale (sample item: "The truth I see in other worldviews leads me to reexamine my current views.") aims at the conjunctive faith in Fowler's model or to what Streib (2001) called the dialogical religious style. The three subscales address three different concerns, three different visions for positive experiences-which, according to our definition of schema, constitute three distinct religious schemata: $t t t$ is preoccupied with the concern for one's own religion and with the envisioned positive experience of its unchallenged integrity, $f t r$ features the concern and vision of a fair coexistence of the religions, and xenos is concerned with preserving openness and features as positive experience the creative surplus in interreligious encounters. Figure 3 presents the way in which the 15 items of the RSS identify three schemata that fall into three factors and how each schema is related to the religious styles (which, in turn, relate to Fowler's stages, to recall Figure 1). The comprehensive list of items of the 15-items, three-subscales Religious Schema Scale are presented in the appendix.

Even though each of the three RSS subscales, $t t t$, ftr, and xenos, have their primary focus on specific schemata, they form a superordinate scale. The total RSS score is obtained by reverse scoring $t t t$ and adding this to the other two subscale totals. This algorithm derives plausibility from the negative correlations of $t t t$ with xenos and positive correlations between ftr and xenos (see Table 3).

\section{CFA}

To test the theoretical structure of the 15 -items, three-subscales final instrument, CFA with split U.S. $(n=567)$ and German $(n=255)$ sample and with the combined sample $(N=822)$ have been calculated with AMOS 17.0 according to the procedure described by Byrne (2001, 2004). The theoretical three-factorial structure of the theoretical model is depicted in Figure 4. Due to the coordination center of the Bielefeld-Based Cross-Cultural Study of Deconversion (Streib et al., 2009), the theoretical model has first been tested based on the data of the German 


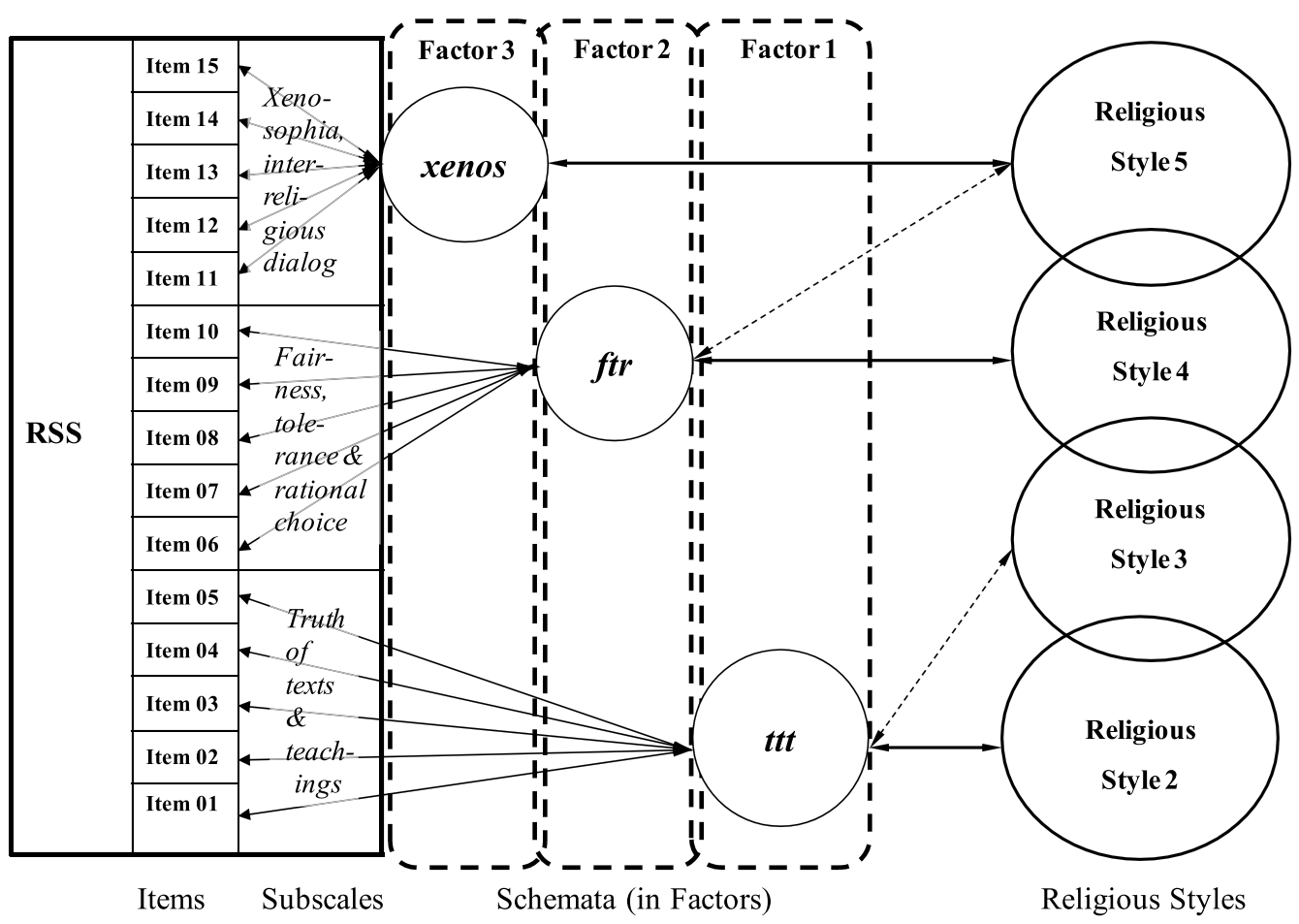

FIGURE 3 Relation of RSS Items, Religious Schemata and Religious Styles

subsample. Additional analyses based on the U.S. and the combined samples were calculated to test whether the model is invariant across both investigated cultures.

As first results the commonalities and the standardized regression weights of the 15 items, which have been found in the CFAs for both subsamples and the combined sample, are reported in Table 1. In addition, the internal consistencies are integrated in the table.

Although not all items load totally satisfying on the three postulated factors-in particular Item 7 in the German subsample and Item 14 in the U.S. subsample have low standardized regression weights, and as a consequence, both items load also low in the combined samplewe have found acceptable or good reliabilities in the two subsamples and in the combined sample. Therefore - and on behalf of scales of similar length - these items have not been deleted. Further research will show if a replacement of these items seems to be necessary. Commonalities in most cases are on a medium level indicating that there is at least some heterogeneity within the three factors. The most homogeneous factor is the one emerging from the $t t$ subscale, which has also the best internal consistency. Although there are some observable differences in the single regression weights and commonalities, it depends on the results of a multigroup CFA whether the whole structure of the theoretical model is invariant between German and U.S. sample.

The results for the fit indices for the model as a whole are presented in Table 2. Fit indices are reported both for the single-group CFA analyses and for a CFA based on the entire sample. 


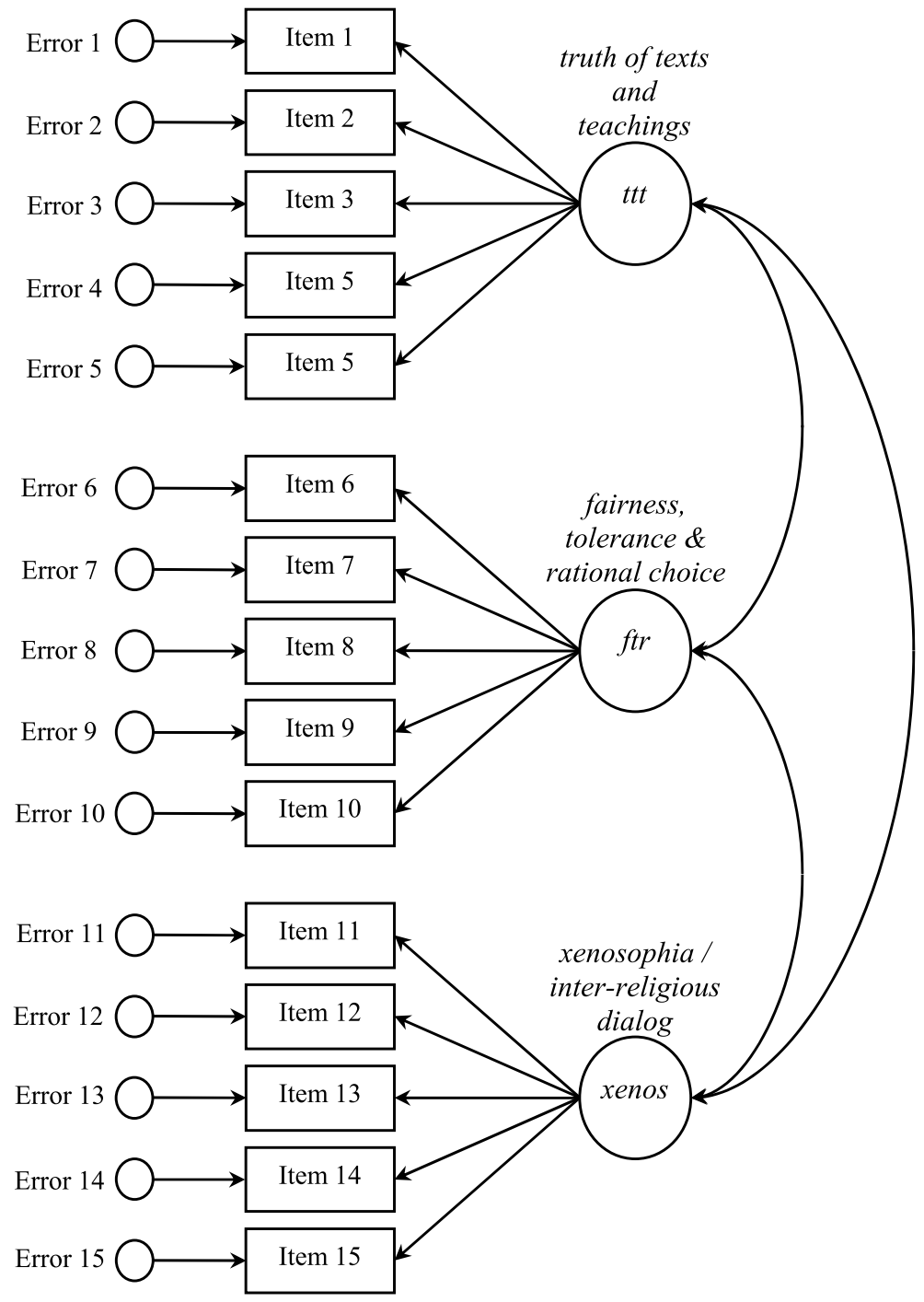

FIGURE 4 Theoretical CFA Model of the RSS

Furthermore, a multigroup CFA was calculated to test the invariance of the theoretical model between both subsamples. The unconstrained model parameters and the model test for equal factor loadings are presented in Table 2 as results of the multigroup CFA. As indices for the CFA results, chi-square, degrees of freedom, $p$ value, comparative fit index (cf. Bentler, 1990), root mean square error of approximation (RMSEA; cf. Steiger, 1990) with 90\% confidence intervals, and standardized root mean residual (cf. Hu \& Bentler, 1995) are reported. According to Beauducel and Wittmann (2005), this selection of indices bears the most valid information for the evaluation of CFA results (cf. also Hu \& Bentler, 1999). 
TABLE 1

CFA Factor Loadings and Communalities of the RSS Items and Internal Consistencies of the Three RSS Subscales

\begin{tabular}{|c|c|c|c|c|c|c|c|c|c|}
\hline & \multicolumn{3}{|c|}{$\begin{array}{l}\text { German Sample } \\
\quad(n=255)\end{array}$} & \multicolumn{3}{|c|}{ US Sample $(n=567)$} & \multicolumn{3}{|c|}{ Total $(n=822)$} \\
\hline & $h^{2}$ & $\begin{array}{c}\text { Stand. } \\
\text { Regr: } \\
\text { Weights }\end{array}$ & $\begin{array}{l}\text { Cronbach's } \\
\text { Alpha }\end{array}$ & $h^{2}$ & $\begin{array}{c}\text { Stand. } \\
\text { Regr. } \\
\text { Weights }\end{array}$ & $\begin{array}{l}\text { Cronbach's } \\
\text { Alpha }\end{array}$ & $h^{2}$ & $\begin{array}{c}\text { Stand. } \\
\text { Regr. } \\
\text { Weights }\end{array}$ & $\begin{array}{l}\text { Cronbach's } \\
\quad \text { Alpha }\end{array}$ \\
\hline $\begin{array}{l}\text { truth of texts } \\
\text { and teachings }\end{array}$ & & & .87 & & & .87 & & & .87 \\
\hline Item 1 & .69 & .83 & & .48 & .69 & & .54 & .74 & \\
\hline Item 2 & .30 & .54 & & .62 & .78 & & .48 & 69 & \\
\hline Item 3 & .60 & .77 & & .51 & .72 & & .54 & .74 & \\
\hline Item 4 & .67 & .82 & & .70 & .83 & & .68 & .82 & \\
\hline Item 5 & .67 & .82 & & .65 & .80 & & .66 & .81 & \\
\hline $\begin{array}{l}\text { fairness, tolerance, } \\
\text { and rational choice }\end{array}$ & & & .65 & & & .70 & & & .69 \\
\hline Item 6 & .28 & .53 & & .34 & .58 & & .32 & .56 & \\
\hline Item 7 & .08 & .28 & & .25 & .50 & & .20 & .45 & \\
\hline Item 8 & .45 & .67 & & .33 & .58 & & .37 & .60 & \\
\hline Item 9 & .28 & .53 & & .29 & .54 & & .29 & .53 & \\
\hline Item 10 & .41 & .64 & & .41 & .64 & & .42 & .65 & \\
\hline $\begin{array}{l}\text { xenosophial } \\
\text { inter-religious dialog }\end{array}$ & & & .82 & & & .66 & & & .73 \\
\hline Item 11 & .57 & .76 & & .32 & .57 & & .44 & .66 & \\
\hline Item 12 & .60 & .78 & & .34 & .58 & & .45 & .67 & \\
\hline Item 13 & .36 & .60 & & .31 & .56 & & .32 & .57 & \\
\hline Item 14 & .45 & .67 & & .11 & .33 & & .22 & .47 & \\
\hline Item 15 & .38 & .62 & & .32 & .57 & & .32 & .57 & \\
\hline
\end{tabular}

TABLE 2

CFA Fit Indices for German Sample, US Sample, and Combined Sample

\begin{tabular}{|c|c|c|c|c|c|c|c|}
\hline Sample & $X^{2}$ & $D F$ & $p$ & $C F I$ & $R M S E A$ & $\begin{array}{l}90 \% C I \\
\text { RMSEA }\end{array}$ & $S R M R$ \\
\hline \multicolumn{8}{|l|}{ Original theoretical model } \\
\hline Model for German sample & 152,36 & 87 & $<.001$ & .95 & .05 & $.04-.07$ & .05 \\
\hline Model for US sample & 273,79 & 87 & $<.001$ & .92 & .06 & $.05-.07$ & .07 \\
\hline $\begin{array}{l}\text { Model for total sample } \\
\text { Multigroup analysis }\end{array}$ & 344,67 & 87 & $<.001$ & .93 & .06 & $.05-.07$ & .06 \\
\hline Unconstrained model & 538,56 & 192 & $<.001$ & .91 & .05 & $.04-.05$ & .09 \\
\hline Equal factor loadings & 731,25 & 207 & $<.001$ & .86 & .06 & $.05-.06$ & .09 \\
\hline \multicolumn{8}{|c|}{$\begin{array}{l}\text { Respecified theoretical model } \\
\text { (covariance between the error } \\
\text { terms of items } 11 \text { and 14) }\end{array}$} \\
\hline Model for German sample & 148,42 & 86 & $<.001$ & .95 & .05 & $.04-.07$ & .05 \\
\hline Model for US sample & 230,18 & 86 & $<.001$ & .94 & .05 & $.05-.06$ & .06 \\
\hline $\begin{array}{l}\text { Model for total sample } \\
\text { Multigroup analysis }\end{array}$ & 295,69 & 86 & $<.001$ & .94 & .05 & $.05-.06$ & .05 \\
\hline Unconstrained model & 491,61 & 190 & $<.001$ & .92 & .04 & $.04-.05$ & .09 \\
\hline Equal factor loadings & 547,23 & 206 & $<.001$ & .91 & .05 & $.04-.05$ & .09 \\
\hline
\end{tabular}


The chi-square tests yield significant results indicating that an exact fit between theoretical model and data could not be found. However, especially for larger samples, it is quite difficult to find the empirical data perfectly fitting to the theoretical model. The fit indices become thus more important (Fan, Thompson, \& Wang, 1999; Jöreskog \& Sörbom, 1993). The CFI values should at least be higher than .90 to be acceptable and should reach a level of approximately .95 for a satisfying fit. This criterion applies for all tested models except for the multigroup test for equal factor loadings (.86). Thus, although the overall factorial structure is invariant across both cultures, due to the divergent regression weightsin particular those of Items 11 and 14-the factor loadings differ between U.S. and German sample.

For samples with more than 250, RMSEA should be smaller than .06. This applies also for all models, although, taking the confidence intervals into account, there is a small risk that the RMSEA values could be slightly higher than .06. But at least in the case of the German subsample, this objection becomes less important, because the German subsample can be regarded as rather small $(n=255)$, and for smaller samples the critical cutoff is increased to .08 (Browne \& Cudeck, 1993). Therefore, taken together, the RMSEA values support the models' quality with high probability. At least, SRMR should be .11 or less, which applies obviously for all models.

In Table 2, we also report results of a respecified theoretical model. For the achievement of an even better model fit it would be possible to integrate the covariance between the error terms of Item 11 ("We can learn from each other what ultimate truth each religion contains.") and Item 14 ("Religious stories and representations from any religion unite me with the ultimate universe.") of the xenos subscale. This covariance was found to have by far the largest Modification Index for an error term covariance, displaying that a respecification of the model by integrating this covariance would meliorate the model fit for $\mathrm{MI}=40,51$. Respecifying CFA models based on Modification Indices means leaving the confirmatory mode of the factor analysis in its truest sense, but it can be plausible if both items have similar contents (Byrne, 2001). In fact, Item 11 and Item 14 have even more similar contents than the other three items of the xenos subscale, as only these two items deal with an ultimate meaning that all religious traditions share. If the covariance between the error terms of Item 11 and Item 14 is integrated in the CFA model, the fit indices improve considerably. The results of CFAs based on the respecified model for both subsamples, for the entire sample, and for the multigroup analyses are reported in the second part of Table 2. Here, all fit indices are satisfying, even the model test for equal factor loadings in the multigroup CFA for the German and the U.S. subsamples. Because, however, according to Brown (2006), CFA model revisions based on Modification Indices tend to result in unstable, hard-to-replicate solutions that might more or less capitalize on chance, we advocate not to perform this respecification in further analyses with the RSS but to use the original, already satisfying model.

Taken together, the CFA results confirm a robust three-factor structure of the RSS. All items from one schema load consistently on one of the three latent variables. The best results could be found for the originally tested German subsample, but, although some differences between few regression weights and commonalities exist, also the analyses for the U.S. subsample and the combined sample yield satisfying results. Cross-cultural validity is supported in regard to the same factor structure that could be confirmed by the CFA models for the U.S. and German samples and the combined sample. 


\section{Correlation Analysis}

Intercorrelations of the RSS subscales. In Table 3 we report the correlations between the three schemata constructs as found in the CFAs based on the original theoretical model and the conventional subscale intercorrelations. Correlations between the RSS subscales are moderate or high and significant on the .01 level. The only exception is the correlation between $t t t$ and $f t r$, which is insignificant and around zero in the German subsample, very low but significant or slightly significant in the U.S. subsample, and very low and slightly significant (CFA correlation) or insignificant (subscales intercorrelation) in the combined sample. This indicates that these two schemata are rather independent and perhaps orthogonal.

As expected, a negative correlation exists between $t t t$ and xenos, stronger in the German than in the U.S. sample, resulting in $r=-.37, p>.001$ (CFA Correlation) and $r=-.30, p>$ .001 (Subscale Correlation) for the combined sample. This indicates an oppositional relation between $t t t$ and xenos, but this opposition is not linear as if xenos were just the reverse of $t t t$. The more complex, rather triangular (see Figure 2) relation between the three subscales is further demonstrated by the fact that ftr correlates considerably and significantly with xenos in both cultures.

Correlation of the RSS with other measures. We can report significant correlations of the RSS subscales and total score with other measures that have been included in the deconversion project. These are presented in Table 4 for both the German and the U.S. sample.

TABLE 3

CFA Correlations and Subscale Intercorrelations Between the RSS Scales in the German and the US Sample

\begin{tabular}{|c|c|c|c|c|c|c|}
\hline & & \multirow{2}{*}{$\begin{array}{c}\text { Truth of } \\
\text { Texts \& } \\
\text { Teachings }\end{array}$} & \multicolumn{2}{|c|}{$\begin{array}{l}\text { Fairness, Tolerance } \\
\quad \& \text { Rationality }\end{array}$} & \multicolumn{2}{|c|}{$\begin{array}{l}\text { Xenosophia/Inter- } \\
\text { Religious Dialogue }\end{array}$} \\
\hline & & & GER & USA & $G E R$ & USA \\
\hline \multirow{5}{*}{$\begin{array}{l}\text { truth of texts \& } \\
\text { teachings }\end{array}$} & CFA Correlation & 1 & .00 & $.14 * *$ & $-.50^{* *}$ & $-.31 * *$ \\
\hline & Sig. & & .962 & .009 & $<.001$ & $<.001$ \\
\hline & Subscale Correlation & & -.01 & $.09 *$ & $-.44 * *$ & $-.22 * *$ \\
\hline & Sig. (2-tailed) & & .903 & .042 & $<.001$ & $<.001$ \\
\hline & $\mathrm{N}$ & & 255 & 567 & 255 & 567 \\
\hline \multirow{5}{*}{$\begin{array}{l}\text { fairness, tolerance \& } \\
\quad \text { rationality }\end{array}$} & CFA Correlation & $.10 *$ & \multirow{5}{*}{\multicolumn{2}{|c|}{1}} & $.59 * *$ & $.60 * *$ \\
\hline & Sig. & .022 & & & $<.001$ & $<.001$ \\
\hline & Subscale Correlation & .05 & & & $.44 * *$ & $.39 * *$ \\
\hline & Sig. (2-tailed) & .134 & & & $<.001$ & $<.001$ \\
\hline & $\mathrm{N}$ & 822 & & & 255 & 567 \\
\hline \multirow{5}{*}{$\begin{array}{l}\text { xenosophia/inter- } \\
\text { religious dialogue }\end{array}$} & CFA Correlation & $-.37 * *$ & \multicolumn{2}{|c|}{$.55 * *$} & \multicolumn{2}{|c|}{1} \\
\hline & Sig. & $<.001$ & \multicolumn{2}{|c|}{$<.001$} & & \\
\hline & Subscale Correlation & $-.30 * *$ & \multicolumn{2}{|c|}{$.37 * *$} & & \\
\hline & Sig. (2-tailed) & $<.001$ & \multicolumn{2}{|c|}{$<.001$} & & \\
\hline & $\mathrm{N}$ & 822 & \multicolumn{2}{|c|}{822} & & \\
\hline
\end{tabular}

*Correlation is significant at the 0.05 level (2-tailed). **Correlation is significant at the 0.01 level (2-tailed). 
TABLE 4

Correlations of RSS with Selected Other Measures

\begin{tabular}{|c|c|c|c|c|c|c|c|c|c|c|}
\hline & \multicolumn{2}{|c|}{ Openness } & \multicolumn{2}{|c|}{$\begin{array}{l}\text { Personal } \\
\text { Growth }\end{array}$} & \multicolumn{2}{|c|}{$\begin{array}{l}\text { Purpose } \\
\text { in Life }\end{array}$} & \multicolumn{2}{|c|}{$\begin{array}{c}\text { Religious } \\
\text { Fundamentalism }\end{array}$} & \multicolumn{2}{|c|}{$\begin{array}{c}\text { Right-Wing } \\
\text { Authoritarianism }\end{array}$} \\
\hline & $G E R^{\mathrm{a}}$ & $U S A^{\mathrm{b}}$ & $G E R^{\mathrm{c}}$ & $U S A^{\mathrm{d}}$ & $G E R^{\mathrm{a}}$ & $U S A^{\mathrm{d}}$ & $G E R^{\mathrm{a}}$ & $U S A^{\mathrm{d}}$ & $G E R^{\mathrm{e}}$ & $U S A^{\mathrm{b}}$ \\
\hline$t t t$ & $-.32 * *$ & $-.34 * *$ & $-.13 *$ & .05 & $.14^{*}$ & $.25 * *$ & $.80 * *$ & $.81 * *$ & $.69 * *$ & $.72 * *$ \\
\hline ftr & $.28 * *$ & $.32 * *$ & $.21 * *$ & $.51 * *$ & $.13^{*}$ & $.34 * *$ & $-.22 * *$ & $-.16^{* *}$ & $-.28 * *$ & $-.21 * *$ \\
\hline xenos & $.41 * *$ & $.35 * *$ & $.21 * *$ & $.26 * *$ & -.06 & $.06 *$ & $-.69 * *$ & $-.42 * *$ & $-.62 * *$ & $-.42 * *$ \\
\hline RSS total & $.46^{* *}$ & $.50 * *$ & $.24 * *$ & $.29 * *$ & -.07 & -.00 & $-.85^{* *}$ & $-.78 * *$ & $-.77 * *$ & $-.74 * *$ \\
\hline
\end{tabular}

Note. ${ }^{\mathrm{a}} \mathrm{N}=254 .{ }^{\mathrm{b}} \mathrm{N}=566 .{ }^{\mathrm{c}} \mathrm{N}=255 .{ }^{\mathrm{d}} \mathrm{N}=567 .{ }^{\mathrm{e}} \mathrm{N}=252 ; * p<.05 . *^{*} p<.01$.

Positive and negative correlations of religious fundamentalism and the RSS are very high in both cultures: positive with $t t t(r=.80, p<.001$ for the German; $r=.81, p<.001$ for the U.S. sample), negative with xenos $(r=-.68, p<.001$ for the German; $r=-.42, p<.001$ for the U.S. sample), and negative with RSS total ( $r=-.85, p<.001$ for the German; $r=$ $-.78, p<.001$ for the U.S. sample). This indicates strong parallels between the two measures. In a similar way but less extreme are the correlations between right-wing authoritarianism and the RSS total and RSS subscales $t t t$ and xenos. This indicates a greater distance of the RSS to right-wing authoritarian attitudes compared to fundamentalist mentality. Rather low negative correlations of $f t r$ with both religious fundamentalism and right-wing authoritarianism indicate a place for $f t r$ somewhere in the middle between $t t t$ and xenos.

From the Big Five dimensions, only openness to experience has considerable correlations with the RSS: negative with $t t$, positive with xenos and-only slightly lower-with $f t r$; RSS total correlates with openness to experience close to .50 in both cultures. Finally, from Ryff's Well-Being Scale, personal growth and purpose in life correlate with the RSS with noteworthy significance and strength; of interest, here it is especially ftr, which has correlations with both personal growth and purpose in life, but only in the U.S. sample.

\section{Validity Analyses}

Predictive validity: Correlations of the RSS with FDI scores. Our database contains FDI ratings of 104 research participants from whom we also have data on the RSS. This unique opportunity suggests relating both results. Correlation analysis of the three RSS schemata and the FDI scores are presented in Table 5.

Not all correlations between FDI scores and the RSS are significant: This is true for ftr in both cultures, and also for xenos in the U.S. sample. The considerable difference between Germany and the United States in regard to the correlation of xenos and FDI scores calls for closer scrutiny in future research. However, we see rather strong (negative) correlation between $t t t$ and FDI scores. This qualifies the $t t t$ subscale as the most valid indicator for faith stages. For the RSS total, we derive a correlation of $.43(p<.001)$ between FDI scores and RSS total in combined sample. 
TABLE 5

Correlations of FDI Ratings with RSS Scales in German and US Sample

\begin{tabular}{clcccc}
\hline & & ttt & $f t r$ & xenos & RSS Total \\
\hline Faith Development & in German Sample & $-.55^{* *}$ & .04 & $.47^{* *}$ & $.53^{* * *}$ \\
Interview Scores & in US Sampleb & $-.47^{* *}$ & -.07 & .14 & $.37^{*}$ \\
& in Combined Sample & $-.51^{* *}$ & -.04 & $.28^{*}$ & $.43^{* *}$ \\
\hline
\end{tabular}

Note. $\quad{ }^{\mathrm{a}} \mathrm{N}=60 .{ }^{\mathrm{b}} \mathrm{N}=44 .{ }^{\mathrm{c}} \mathrm{N}=104 ; * p<.05 . * * p<.01$.

We conclude that our data indicate moderate predictive validity of the RSS scores in respect to FDI scores. But these correlations are not strong enough to evidence that the RSS is measuring exactly the same thing as the FDI.

\section{Incremental Validity: Multiple Regression Analysis}

The incremental validity of the RSS could be best shown by a comparison to Altemeyer and Hunsberger's (1992, 2005) well-established Religious Fundamentalism Scale (RF). According to the religious styles perspective, religious fundamentalism corresponds to the instrumentalreciprocal religious style, which is characterized by strong consent to the truth of texts and teachings. The RF and the RSS subscale $t t t$ have common characteristics. Thus, we could expect that the $t t t$ subscale strongly corresponds with religious fundamentalism, whereas the other two RSS subscales contain elements that differ strongly from fundamentalism schemata. Incremental validity of the RSS should therefore derive from the alternative styles operationalized in the two subscales ftr and xenos, in particular in relation to measures of ideological, religious, and cultural openness, which are usually inversely correlated with measures of fundamentalism.

To illustrate the incremental validity of the RSS in comparison with the RF, a multiple linear regression analysis was conducted using the NEO-FFI openness to experience subscale as dependent variable. Openness to experience was chosen for two reasons: First, openness to experience is the personality dimension that correlates most significantly with religious fundamentalism and with measures of an open, mature religiosity (Saroglou, 2002) or spiritual openness (Csarny, Piedmont, Sneck, \& Cheston, 2000; Piedmont, 2005; cf. also our correlations in Table 4). Thus, for both RF and the RSS — which functions as a measure of religious schemata related to fundamentalism ( $t t t)$ and to open and mature religious orientations ( $f t r, x e n o s)$-we may expect significant effects on openness. Second, although there are numerous measures for religious fundamentalism (e.g., Altemeyer \& Hunsberger, 1992; Gibson \& Francis, 1996; Gorsuch \& Smith, 1983), religious orthodoxy (Fullerton \& Hunsberger, 1982; Stellway, 1973) or scriptural literalism (Duriez, Fontaine, \& Hutsebaut, 2000; Duriez, Soenens, \& Hutsebaut, 2005; Hogge \& Friedman, 1967), and several measures for liberal and pluralistic religious orientations (Burris \& Tarpley, 1998; Duriez et al., 2000; Duriez, Soenens, \& Hutsebaut, 2005; Huber, 2009; Kaldestad \& Stifoss-Hanssen, 1993; Stellway, 1973), none of these deals specifically with the challenges of interreligious dialog and the encounter with the alien (although some scales might include few items which are related to this topic, e.g., Burris \& Tarpley, 1998; Huber, 2009). But these challenges are the focus of the RSS subscales ftr and xenos, in particular. And because openness to something alien and to interreligious 
dialog probably correspond with a more open personality, openness to experience seems to be a suitable validation criterion to illustrate the positive associations between interreligious openness and an open-minded personality in general.

The regression was calculated in three steps to confirm the incremental validity of the RSS, with the first step including the sociodemographic variables gender, age, and education; the second step including RF; and the third step including the three RSS subscales. Within each step the inclusion algorithm was employed. Thus, the amount of variance that is explained by the RSS subscales beyond the effects of sociodemographic variables and RF is observable. The results of the multiple regression analysis are shown in Table 6.

As Table 6 shows, there is no significant effect of age or gender, but education was found to be significantly relevant for a general orientation toward openness to experience-which is, however, not surprising because education nurtures the ability to deal with new experience in an open way. Interesting for the question of incremental validity of the RSS is the finding that two RSS subscales, ftr and xenos, and RF have significant effects on openness to experience, with $f t r$ having a stronger effect than xenos. Whereas $f t r$ and xenos yield substantial positive effects indicating that more religious fairness and tolerance and more xenosophical orientations go along with more openness in general, the relation between RF and openness to experience is inverse as expected. The more fundamentalist our respondents answered, the less did they agree with openness items on average.

The effect of the RSS subscale ttt on openness to experience did not reach significance in this regression analysis. This is probably due to $t t t$ 's collinearity with RF. As presented in Table 4, religious fundamentalism and $t t$ are highly correlated with each other $(r=.80, p<$ $.001)$, and RF $\left(\sigma^{2}=285,68\right)$ has by far the larger variance than $t t t\left(\sigma^{2}=19,37\right)$; thus, in the regression analysis, only RF became significant. Because of the high correlation between both scales it is likely that facets of the same construct are measured. The assumption may be plausible that strong belief in the truth of sacred texts and traditional teachings constitutes a main —if not the core-element of a fundamentalist religious style (cf. the characterization

TABLE 6

Multiple Regression Analysis Comparing the Religious Schema Scale with the Religious Fundamentalism Scale Using openness to experience as Dependent Variable

\begin{tabular}{|c|c|c|c|c|c|c|c|c|c|}
\hline & \multicolumn{3}{|c|}{ Step 1} & \multicolumn{3}{|c|}{ Step 2} & \multicolumn{3}{|c|}{ Step 3} \\
\hline & Beta & $T$ & $p$ & Beta & $T$ & $p$ & Beta & $T$ & $p$ \\
\hline Age & .074 & 2,119 & .034 & .051 & 1,605 & .109 & .039 & 1,243 & .214 \\
\hline Gender & -.022 & $-0,581$ & .561 & -.020 & $-0,566$ & .571 & -.019 & $-0,560$ & .576 \\
\hline Education & .309 & 7,913 & $<.001$ & .224 & 6,156 & $<.001$ & .213 & 5,969 & $<.001$ \\
\hline Religious Fundamentalism & & & & -.398 & $-12,391$ & $<.001$ & -.255 & $-4,156$ & $<.001$ \\
\hline truth of texts and teachings & & & & & & & -.078 & $-1,401$ & .162 \\
\hline $\begin{array}{l}\text { fairness, tolerance, and } \\
\text { rational choice }\end{array}$ & & & & & & & .176 & 5,248 & $<.001$ \\
\hline $\begin{array}{l}\text { xenosophia and } \\
\text { interreligious dialog }\end{array}$ & & & & & & & .105 & 2,790 & .005 \\
\hline Adjusted $\mathrm{R}^{2}$ & & .084 & & & .235 & & & .275 & \\
\hline
\end{tabular}


of fundamentalism as intratextuality by Hood, Hill, \& Williamson, 2005). But for the RSS's incremental validity, the $t t t$ subscale is of less importance because $f t r$ and, in particular, xenos are the subscales which introduce new facets in the measurement of (inter)religious attitudes, and the latter two were significant even after controlling for RF. Ttt's worth for the psychology of religion derives from the opportunity to use it as part of the complete RSS to study styles of religious thinking and behavior differentially. This opens a perspective on the additional benefit of the RSS measures which we address in the next section.

\section{DISCUSSION}

The reduction of the RSS to the 15 -item version could successfully be completed in a procedure that has balanced concern for conceptual consistency and statistical concerns for reliability and various dimensions of validity. However, item reduction is not simply a statistical routine with little relation to the concept. It is a reduction of aspects or, stated positively, it is a focusing on specific aspects of religion and faith. The RSS is a new measure that, according to this initial test, is of sufficient reliability and validity to indicate three religious schemata: $t t t$ for a religious style in which preoccupation with the truth of one's own religion plays a central role, $f t r$ for a religious style in which openness for fairness and tolerance stands in the foreground, and xenos for a religious style which is characterized by the appreciation of the alien and thus by interreligious dialog.

As the correlations between the three subscales indicate, a strong focus of the RSS is religious absolutism or fundamentalism and its possible developmental ways out: interreligious dialog/xenosophia and fairness, tolerance and rational reflection. Extraordinary high correlations of $t t t$ of the RSS with Altemeyer and Hunsberger's (1992) RF would even suggest considering this subscale as a measure of fundamentalism - which, in contrast to the RF, would be less culture specific, less dogmatism oriented. Further, the integration of the $t t t$ subscale with the two other subscales into one RSS scale has the advantage of accounting at the same time for developmental juxtapositions of fairness, tolerance, xenosophia, and readiness for interreligious dialog, which we conceptually posit as the counterparts of fundamentalism. This was the result of the test for incremental validity with openness to experience as dependent variable.

At first glance, one might understand the opposition of the RF effect, on one hand, and the $f t r$ and xenos effects, on the other, as it has emerged in our test for incremental validity (Table 6), as a trivial finding, because they seem to be interpretable as the opposed poles of a single dimension that may parallel the open-closed tension. This seems to be true in particular for RF and xenos which are highly inversely correlated $(r=-.52, p<.001)$. However, this does not appear trivial anymore, if we take into account that the RSS includes both ends of a spectrum in one scale and thus avoids an exclusive focus on the supposed "pathological" aspects. To make this argument plausible, we may recall the enormous impact that the paradigm change from a pathogenetical to the salutogenetical perspective has had on health research since the late 1970s. Antonovsky's $(1979,1987)$ concept of salutogenesis opened up this new perspective on the health pole of the illness-health continuum and inspired a completely new direction of research in scientific disciplines and in health service.

If we transfer this perspective to the field of research on religious styles, we might assume that fundamentalism, on one end, and tolerance and xenosophia, on the other, are opposing 
poles. But focusing on the fair and tolerant or dialogical and xenosophic poles means something totally different than watching the fundamentalist pole only. In practical terms: Whenever religious education intends to promote tolerance or openness for interreligious dialog, it is not enough to devaluate fundamentalism; rather, it is important to focus on the aspired goal, and this involves nurturing a learning process toward knowledge and practice of a tolerant, but more: of a dialogical and xenosophical style. Thus, one of the central aims of the RSS is to enable research on style differences within the fields of the psychology of religion-thereby, however, operationalizing not merely the fundamentalist schema but the alternative schemata as well. The incremental validity of the RSS in comparison with the RF is the opportunity to measure several schemata as distinguishing marks for differing religious styles, whereas the RF measures only one pole.

Thus, the RSS provides the opportunity to relate faith development research and the model of religious styles to attitudinal research in psychology of religion: $t t t$ very likely is highly associated with religious exclusivism, ftr with religious pluralism, individuative-reflective or individuative styles, whereas xenos introduces and highlights still another perspective: the creative surplus of the alien which the conjunctive or dialogical style features. Thus, based on the assumption that the decline of absoluteness claims $(t t t)$ and style developments toward tolerance ( $f t r$ ), but especially toward the readiness for interreligious dialog (xenos) is a developmental progress, the RSS is an instrument to assess religious development.

The RSS is a contribution to religious development and religious styles research, but it should not be understood simply as measure for faith development or even as replacement of the FDI. The moderate correlations of RSS scores in relation to FDI ratings support this reservation. Rather, these moderate correlations may be taken as indication that the RSS is an independent measure with a precise focus of its own. Certainly, the RSS has a potential to identify distinguishing marks for religious styles and stages of faith, but the special contribution of the RSS is its potential to indicate the variety, and potential difference in strength, of different schemata in one person at one time. The focus of the RSS is on interindividual and on intraindividual difference. This is played down in the current FDI evaluation procedure by simply calculating an average sum score and widely ignored in previous proposals for quantitative faith development measures, as far as they operate with single scores as indices for faith stages. The RSS can be appreciated only, when "structural wholes" are not presupposed and when overlaps of styles are not excluded by a priori premises but when instead religious styles - and faith stages - are understood as composites of religious schemata. The RSS can be seen as a measure that allows the assessment of "dormant" styles which may (or may not) be reactivated later in development. Even though we would expect too much from the RSS when it should serve as a measure to identify the reasons why dormant styles are reactivated by some and not by others, the RSS is introduced as new measure in the psychology of religion/psychology of religious development, because it may be helpful in identifying religious development with focus on the overcoming the absolutist and fundamentalist style in a more differential way.

This study presented the development of the RSS and its initial validation but should be regarded as still exploratory. We hope that future research may allow further testing of the RSS and shed more light on the relation of the RSS with personality traits, with health measures and with interreligious attitudes. To detail as example the interreligious perspective: Styles of interreligious negotiation can be differentiated into a spectrum reaching from xenophobic 
and imperialistic mono-religious styles, through implicitly and explicitly multireligious styles finally to an interreligious-dialogical style (Streib, 2006). These styles of interreligious dialog very likely interact with $t t t$, ftr, and especially with xenos. Thus, the RSS may have potential to investigate interreligious hermeneutics - with explicit and precise focus on something highly desirable: xenosophia.

\section{REFERENCES}

Altemeyer, B. (1996). The authoritarian specter. Cambridge, MA: Harvard University Press.

Altemeyer, B., \& Hunsberger, B. (1992). Authoritarianism, religious fundamentalism, quest and prejudice. The International Journal for the Psychology of Religion, 2, 113-133.

Altemeyer, B., \& Hunsberger, B. (2005). Fundamentalism and authoritarianism. In R. F. Paloutzian \& C. L. Park (Eds.), Handbook of the psychology of religion and spirituality (pp. 378-393). New York: Guilford.

Antonovsky, A. (1979). Health, stress, and coping. San Francisco, CA: Jossey-Bass.

Antonovsky, A. (1987). Unraveling the mystery of health. How people manage stress and stay well. San Francisco, CA: Jossey-Bass.

Beauducel, A., \& Wittmann, W. W. (2005). Simulation study on fit indices in confirmatory factor analysis based on data with slightly distorted simple structure. Structural Equation Modeling, 12, 41-75.

Bentler, P. M. (1990). Comparative fit indexes in structural models. Psychological Bulletin, 107, 238-246.

Bourdieu, P. (1979). Distinction: A social critique of the judgment of taste. Cambridge, MA: Harvard University Press.

Boyatzis, C. J. (2005). Religious and spiritual development in childhood. In R. F. Paloutzian \& C. L. Park (Eds.), Handbook of the psychology of religion and spirituality (pp. 123-143). New York: Guilford.

Brown, T. A. (2006). Confirmatory factor analysis for applied research. New York: Guilford.

Browne, M. W., \& Cudeck, R. (1993). Alternative ways of assessing model fit. In K. A. Bollen \& J. S. Long (Eds.), Testing structural equations models (pp. 136-162). Newbury Park, CA: Sage.

Burris, C. T. (1999). Faith Development Interview guide (Fowler, 1981). In P. C. Hill \& R. W. Hood (Eds.), Measures of religiosity (pp. 163-168). Birmingham, AL: Religious Education Press.

Burris, C. T., \& Tarpley, W. R. (1998). Religion as being: Preliminary validation of the Immanence Scale. Journal of Research in Personality, 32, 55-79.

Byrne, B. M. (2001). Structural equation modeling with AMOS: Basic concepts, applications, and programming. Mahwah, NJ: Erlbaum.

Byrne, B. M. (2004). Testing for multigroup invariance using AMOS graphics: A road less traveled. Structural Equation Modeling, 11, 272-300.

Canfield, R. L., \& Ceci, S. J. (1992). Integrating learning into a theory of intellectual development. In R. J. Sternberg \& C. A. Berg (Eds.), Intellectual development (pp. 278-300). Cambridge, UK: Cambridge University Press.

Clore, V. (1997). Faith development in adults: Scale of measurement and relation to attachment. Unpublished doctoral dissertation, Wayne State University, Detroit, MI. (DAI-B 58/11, p. 6256, May 1998)

Costa, P. T., \& McCrae, R. R. (1985). Revised NEO Personality Inventory (NEO PI-R) and NEO Five-Factor-Inventory (NEO-FFI). Odessa, FL: Psychological Assessment Resources.

Csarny, R. J., Piedmont, R. L., Sneck, W. J., \& Cheston, S. E. (2000). An evaluation of the incremental validity of the Spiritual Experience Index-Revised. Research in the Social Scientific Study of Religion, 11, 117-131.

Day, J. (2007). Moral reasoning, religious reasoning, and their supposed relationships: Paradigms, problems, and prospects. Adult Developments, 10, 6-10.

Day, J. (2008). Human development and the model of hierarchical complexity: Learning from research in the psychology of moral and religious development. World Futures: The Journal of General Evolution, 64, 452-467.

Duriez, B., Fontaine, J. R. J., \& Hutsebaut, D. (2000). A further elaboration of the Post-Critical Belief Scale: Evidence for the existence of four different approaches to religion in Flanders-Belgium. Psychologica Belgica, 40, $153-181$.

Duriez, B., Soenens, B., \& Hutsebaut, D. (2005). Introducing the Shortened Post-Critical Belief Scale. Personality and Individual Differences, 38, 851-857.

Fan, X., Thompson, B., \& Wang, L. (1999). Effects of sample size, estimation methods, and model specification on structural equation modeling fit indexes. Structural Equation Modeling, 6, 56-83. 
Fowler, J. W. (1981). Stages of faith. The psychology of human development and the quest for meaning. San Francisco, CA: Harper \& Row.

Fowler, J. W., \& Dell, M. L. (2006). Stages of faith from infancy through adolescence: Reflections on three decades of faith development theory. In E. C. Roehlkepartain, P. Ebstyne King, L. M. Wagener, \& P. L. Benson (Eds.), The handbook of spiritual development in childhood and adolescence (pp. 34-45). Thousand Oaks, CA: Sage.

Fowler, J. W., Streib, H., \& Keller, B. (2004). Manual for faith development research (3rd ed.). Bielefeld, Germany: Research Center for Biographical Studies in Contemporary Religion.

Fullerton, J. T., \& Hunsberger, B. (1982). A uni-dimensional measure of Christian orthodoxy. Journal for the Scientific Study of Religion, 21, 317-326.

Gennerich, C., \& Huber, S. (2006). Value priorities and content of religiosity-New research perspectives. Archive for the Psychology of Religion, 28, 253-267.

Gibson, H. M., \& Francis, L. J. (1996). Measuring Christian fundamentalist belief among 11-15-year-old adolescents in Scotland. In L. J. Francis \& W. S. Campbell (Eds.), Research in religious education (pp. 249-255). Leominster, UK: Fowler Wright.

Gorsuch, R. L., \& Smith, C. S. (1983). Attributions of responsibility to God: An interaction of religious beliefs and outcomes. Journal for the Scientific Study of Religion, 22, 340-352.

Greimas, A. J. (1987). On meaning: Selected writings in semiotic theory. Minneapolis, MN: University of Minnesota Press.

Hogge, J. H., \& Friedman, S. T. (1967). The Spiritual Literalism Scale: A preliminary report. The Journal of Psychology, $66,275-279$.

Hood, R. W., Jr. (2003). The relationship between religion and spirituality. In D. Bromley (Series Ed.) \& A. L. Greil \& D. G. Bromley (Vols. Eds.), Defining religion: Investigating the boundary between the sacred and the secular; Vol. 10. Religion and the social order (pp. 241-264). Amsterdam: Elsevier.

Hood, R. W., Hill, P. C., \& Williamson, W. P. (2005). The psychology of religious fundamentalism. New York: Guilford.

Hu, L., \& Bentler, P. M. (1995). Evaluating model fit. In R. H. Hoyle (Ed.), Structural equation modeling: Concepts, issues, and applications (pp. 76-99). Thousand Oaks, CA: Sage.

$\mathrm{Hu}$, L., \& Bentler, P. M. (1999). Cutoff criteria for fit indexes in covariance structure analysis: Conventional criteria versus new alternatives. Structural Equation Modeling, 6, 1-55.

Huber, S. (2009). Religion monitor 2008: Structuring Principles, operational constructs, interpretive strategies. In What the world believes: Analysis and commentary on the religion monitor 2008 (pp. 17-51). Gütersloh, Germany: Verlag Bertelsmann Stiftung.

Huber, S., \& Klein, C. (2007). Kurzbericht zu einzelnen Ergebnissen der internationalen Durchführung des Religionsmonitors der Bertelsmann-Stiftung [Brief report about selected results of the International Religion Monitor survey of the Bertelsmann Foundation]. Gütersloh, Germany: Bertelsmann-Stiftung. Available from http://www.bertelsmannstiftung.de/cps/rde/xbcr/SID-0A000F14-9A0B2D07/bst/xcms_bst_dms_23399_23400_2.pdf

Jöreskog, K. G., \& Sörbom, D. (1993). LISREL 8: Structural equation modeling with the SIMPLIS Command Language. Hillsdale, NJ: Erlbaum.

Kaldestad, E., \& Stifoss-Hanssen, H. (1993). Standardizing measures of religiosity for Norwegians. The International Journal for the Psychology of Religion, 3, 111-124.

Kohlberg, L., Levine, C., \& Hewer, A. (1983). The current formulation of the theory. In L. Kohlberg (Ed.), Essays on moral development, Vol. II. (pp. 212-319). San Francisco, CA: Harper \& Row.

Leak, G. K. (2003). Validation of the Faith Development Scale using longitudinal and cross-sectional designs. Social Behavior \& Personality, 31, 637-642.

Leak, G. K. (2008). Factorial validity of the Faith Development Scale. The International Journal for the Psychology of Religion, 18, 123-131.

Leak, G. K., Loucks, A. A., \& Bowlin, P. (1999). Development and initial validation of an objective measure of faith development. The International Journal for the Psychology of Religion, 9, 105-124.

McIntosh, D. N. (1995). Religion-as-schema, with implications for the relation between religion and coping. The International Journal for the Psychology of Religion, 5, 1-16.

Nakamura, Y. (2000). Xenosophie: Bausteine für eine Theorie der Fremdheit [Xenosophia: Building blocks of a theory of alien-mess]. Darmstadt, Germany: Wissenschaftliche Buchgesellschaft.

Park, C. L. (2005). Religion and meaning. In R. F. Paloutzian \& C. L. Park (Eds.), Handbook of the psychology of religion and spirituality (pp. 295-314). New York: Guilford. 
Park, C. L. (2007). Religiousness/spirituality and health: A meaning systems perspective. Journal of Behavioral Medicine, 30, 319-328.

Piedmont, R. L. (2005). The role of personality in understanding religious and spiritual constructs. In R. F. Paloutzian \& C. L. Park (Eds.), Handbook of the psychology of religion and spirituality (pp. 253-273). New York: Guilford.

Power, F. C. (1991). Hard versus soft stages of faith and religious development. In J. W. Fowler, K. E. Nipkow, \& F. Schweitzer (Eds.), Stages of faith and religious development. Implications for church, education, and society (pp. 116-129). New York: Crossroad.

Ryff, C. D., \& Singer, B. H. (1996). Psychological well-being: Meaning, measurement, and implications for psychotherapy research. Psychotherapy and Psychosomatics, 65, 14-23.

Ryff, C. D., \& Singer, B. H. (2006). Best news yet on the six-factor model of well-being. Social Science Research, $35,1103-1119$.

Saroglou, V. (2002). Religion and the five factors or personality: A meta-analytic review. Personality and Individual Differences, 32, 15-25.

Schäfer, H. (2003). Zur Theorie von kollektiver Identität und Habitus am Beispiel sozialer Bewegungen [On the theory of collective identity and habitus: The example of social movements]. Unpublished doctoral dissertation, Humboldt-Universität zu Berlin.

Schäfer, H. (2005). Network identity and religious harmony: Theoretical and methodological reflections. Marburg Journal of Religion, 10(1). Available from http://web.uni-marburg.de/religionswissenschaft/journal/mjr/art_schaefer_ 2005.htm

Schäfer, H. (in press). Explaining Central American pentecostalism within social inequality and conflict. On habitusanalysis as a clue to describe religious praxis. In C. L. Smith (Ed.), Pentecostal power: Expressions, faith and politics of Latin American pentecostalism. Boston: Brill.

Smith, W. C. (1963). The meaning and end of religion. Minneapolis, MN: Fortress Press.

Smith, W. C. (1979). Faith and belief. Princeton, NJ: Princeton University Press.

Steiger, J. H. (1990). Structural model evaluation and modification: An interval estimation approach. Multivariate Behavioral Research, 25, 173-180.

Stellway, R. J. (1973). The correspondence between religious orientation and sociopolitical liberalism and conservatism. Sociological Quarterly, 14, 430-439.

Streib, H. (2001). Faith Development Theory revisited: The religious styles perspective. The International Journal for the Psychology of Religion, 11, 143-158.

Streib, H. (2003). Faith Development Research at twenty years. In R. R. Osmer \& F. Schweitzer (Eds.), Developing a public faith. New directions in practical theology (pp. 15-42). St. Louis, MO: Chalice.

Streib, H. (2005). Faith Development Research revisited: Accounting for diversity in structure, content, and narrativity of faith. The International Journal for the Psychology of Religion, 15, 99-121.

Streib, H. (2006). Strangeness in inter-religious classroom communication: Research on the 'gift-to-the-child' material. In D. Bates, G. Durka, \& F. Schweitzer (Eds.), Education, religion and society (pp. 191-204). London: Routledge.

Streib, H. (2007). Faith development and a way beyond fundamentalism. In C. Timmerman, D. Hutsebaut, S. Mels, W. Nonneman, \& W. van Herck (Eds.), Faith-based radicalism (pp. 151-167). Brussels, Belgium: P.I.E.-Peter Lang.

Streib, H., Hood, R. W., Keller, B., Csöff, R.-M., \& Silver, C. S. (2009). Deconversion. Qualitative and quantitative results from cross-cultural research in Germany and the United States of America (Research in Contemporary Religion, Vol. 5). Göttingen, Germany: Vandenhoeck \& Ruprecht.

Waldenfels, B. (1990). Der Stachel des Fremden [The good of the alien]. Frankfurt, Germany: Suhrkamp.

Waldenfels, B. (1997). Topographie des Fremden [Topography of the alien]. Frankfurt, Germany: Suhrkamp.

Zinnbauer, B. J., \& Pargament, K. I. (2005). Religiousness and spirituality. In R. F. Paloutzian \& C. L. Park (Eds.), Handbook of the psychology of religion and spirituality (pp. 21-42). New York: Guilford. 


\section{APPENDIX \\ The Religious Schema Scale (RSS)}

\begin{tabular}{|c|c|}
\hline Subscales & Items \\
\hline $\begin{array}{l}\text { ttt } \\
\quad \begin{array}{l}\text { (truth of texts } \\
\text { and teachings) }\end{array}\end{array}$ & $\begin{array}{l}\text { 1. What the texts and stories of my religion tell me is absolutely true and must not be } \\
\text { changed. } \\
\text { 2. When people want to know how the world came to be, they need to hear a creation story. } \\
\text { 3. When I have to make a decision, I take care that my plans are acceptable by my } \\
\text { religious teachings. } \\
\text { 4. The stories and teachings of my religion give meaning to the experiences of my life and } \\
\text { reveal the unchangeable truth about God or the Divine. } \\
\text { 5. The teachings of my religion offer answers to any question in my life, if I am ready to } \\
\text { listen. }\end{array}$ \\
\hline $\begin{array}{l}\text { ftr } \\
\quad \text { (fairness, } \\
\text { tolerance, } \\
\text { rational } \\
\text { choice) }\end{array}$ & $\begin{array}{l}\text { 6. When I make a decision, I look at all sides of the issue and come up with the best } \\
\text { decision possible. } \\
\text { 7. Although every person deserves respect and fairness, arguments need to be voiced } \\
\text { rationally. } \\
\text { 8. We should resolve differences in how people appear to each other through fair and just } \\
\text { discussion. } \\
\text { 9. Regardless of how people appear to each other, we are all human. } \\
\text { 10. It is important to understand others through a sympathetic understanding of their culture } \\
\text { and religion. }\end{array}$ \\
\hline $\begin{array}{l}\text { xenos } \\
\quad \text { (xenosophia, } \\
\quad \text { inter-religious } \\
\text { dialog) }\end{array}$ & $\begin{array}{l}\text { 11. We can learn from each other what ultimate truth each religion contains. } \\
\text { 12. We need to look beyond the denominational and religious differences to find the } \\
\text { ultimate reality. } \\
\text { 13. When I make a decision, I am open to contradicting proposals from diverse sources and } \\
\text { philosophical standpoints. } \\
\text { 14. Religious stories and representations from any religion unite me with the ultimate } \\
\text { universe. } \\
\text { 15. The truth I see in other world views leads me to re-examine my current views. }\end{array}$ \\
\hline
\end{tabular}


This article was downloaded by: [Streib, Heinz]

On: 9 July 2010

Access details: Access Details: [subscription number 924017610]

Publisher Routledge

Informa Ltd Registered in England and Wales Registered Number: 1072954 Registered office: Mortimer House, 3741 Mortimer Street, London W1T 3JH, UK

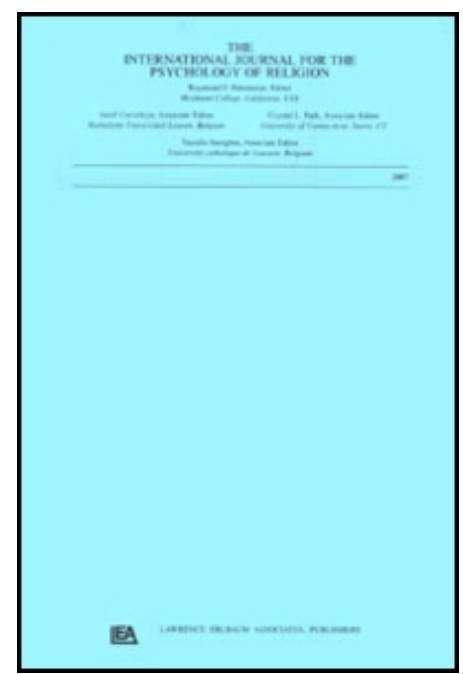

International Journal for the Psychology of Religion

Publication details, including instructions for authors and subscription information:

http://www.informaworld.com/smpp/title $\sim$ content=t775653664

\section{The Religious Schema Scale: Construction and Initial Validation of a} Quantitative Measure for Religious Styles

Heinz Streiba ; Ralph W. Hood Jr.; ; Constantin Klein ${ }^{\text {a }}$

${ }^{a}$ Center for Biographical Research in Contemporary Religion, Universität Bielefeld, ${ }^{\mathrm{b}}$ Department of Psychology, University of Tennessee at Chattanooga,

Online publication date: 07 July 2010

To cite this Article Streib, Heinz, Hood Jr., Ralph W. and Klein, Constantin(2010) 'The Religious Schema Scale: Construction and Initial Validation of a Quantitative Measure for Religious Styles', International Journal for the Psychology of Religion, 20: 3, $151-172$

To link to this Article: DOI: $10.1080 / 10508619.2010 .481223$

URL: http://dx.doi.org/10.1080/10508619.2010.481223

\section{PLEASE SCROLL DOWN FOR ARTICLE}

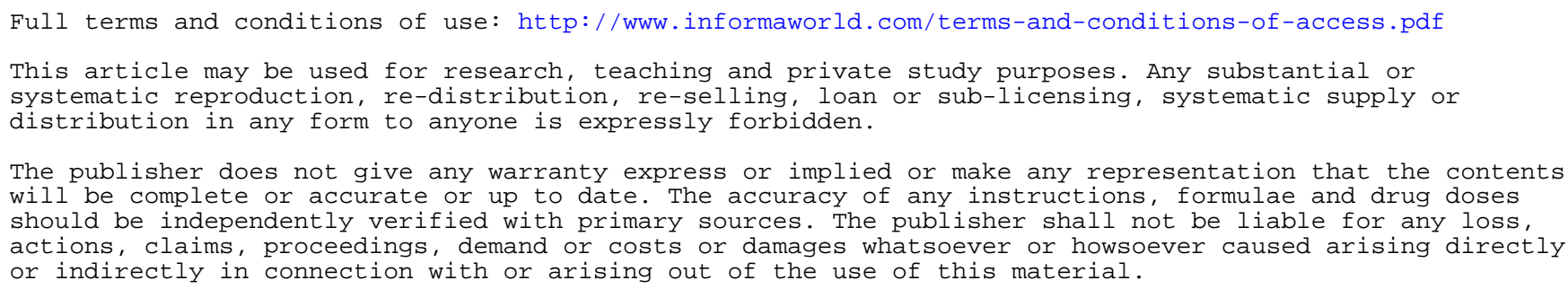

